\author{
Barbara Szotek \\ Uniwersytet Śląski w Katowicach \\ (iD https://orcid.org/0000-0002-0169-1128
}

\title{
Filozofia nowokrytyczna w rozumieniu Stanisława Kobyłeckiego i Mariana Massoniusa
}

\author{
New Critical Philosophy \\ as Understood by Stanisław Kobyłecki and Marian Massonius
}

\begin{abstract}
The issue of neo-kantism and modern criticism is one of the problems discussed by representatives of various philosophical currents in Poland in the late nineteenth and early twentieth centuries. For neo-kantism - with its heteronomy and problems with the delineation of individual positions in it - and, in particular, a strongly undefined modern criticism, practically showing no ideological unity, led to the view that everyone who felt obliged to stick to a scientific discipline, i.e. proclaimed the need to make philosophy more scientific, or only made a superficial accession or acceptance of a general idea, or only some element of it, could find a place within them. It is interesting that even today it is not easy to deal with this problem. It seems that, on the one hand, neo-kantism and modern criticism - primarily in Polish philosophy at the turn of the 19th and 20th centuries can be almost treated synonymously; on the other hand, they are, from one point of view, mutually exclusive options, and, from another, complementary in nature (they are coming closer then, as is claimed, to a positivist criticism).

The article attempts to present, mainly on the basis of two representatives of philosophical thought of that time, viz. Stanisław Kobyłecki and Marian Massonius, the similarities and differences that emerged in the understanding of modern criticism in connection with the publication entitled Filozofia nowokrytyczna [Modern Crititical Philosophy], in which "the turn to Kant" was even put into the formula of "modern criticism".
\end{abstract}

Keywords: Filozofia nowokrytyczna [Modern Crititical Philosophy], Stanisław Kobyłecki, Marian Massonius 


\section{W stronę unaukowienia filozofii}

W pozytywizmie pojawił się nurt tak zwanej filozofii nowokrytycznej, który stanowił w tej epoce drugą, nazywaną krytyczną fazę tego nurtu filozofii rozwijaną pod ogólnym hasłem jej „unaukowienia”. Jednocześnie w filozofii polskiej przełomu XIX i XX wieku filozofia nowokrytyczna była jedną z przynajmniej dwóch orientacji wyznaczających, jak można twierdzić, charakterystyczne tendencje epoki. Przy czym już w latach osiemdziesiątych XIX wieku można było zauważyć kształtowanie się nowej formuly filozoficznej programów antymetafizycznych, zwanej przez jej rzeczników nowokrytycyzmem. Formuła ta jednakże nie odpowiadała pojęciu ,neokantyzm” w jego rozumieniu w filozofii europejskiej — jako określenia dla różnorodnych odmian stanowisk neokantowskich.

Polski nowokrytycyzm był związany przede wszystkim z naturalistyczno-ewolucjonistyczną wykładnią kantyzmu, która mogła być odczytywana jako stanowisko zbieżne z pewnymi tezami pozytywistycznymi. Swój neokantowski akces - jak zaznacza Anna Hochfeldowa - polscy nowokrytycyści traktowali jako wyraz pozytywizmu w jego formie nowoczesnej, to znaczy wzbogaconej krytyczną teorią poznania Immanuela Kanta, przeformułowaną $\mathrm{w}$ duchu ewolucjonizmu i współczesnych osiągnięć psychologii ${ }^{1}$. Znamienną cechą tego kierunku było kontynuowanie tradycji zarówno kantyzmu, jak i wszystkich współczesnych nurtów filozofii pozytywistycznej, od empiriokrytycyzmu po fizykalizm, oraz korzystanie z metodologicznych treści właściwych nowoczesnemu przyrodoznawstwu. Rezonans tak szeroko pojmowanego prądu teoretycznego był dość szeroki, często sprowadzał się jednak do akceptowania pojedynczych tez tego stanowiska. „Nowokrytycyzmowi” okazywali życzliwość przyrodnicy, na przykład Antoni Złotnicki. Wyraźnie skłaniali się ku temu prądowi niektórzy pisarze parający się humanistyką, jak Ignacy Matuszewski czy Piotr Chmielewski. Jako zwolennicy nowokrytycznego programu filozofii naukowej deklarowali się Ludwik Krzywicki i Stanisław Krusiński².

Ze względu na nieokreśloność, fragmentaryczność i powierzchowność tych filozoficznych deklaracji nowokrytycyzm można traktować jako pewną myślową orientację odbiegającą znacznie od teoretycznej jednolitości i jed-

1 A. Hochfeldowa: Neokantyzm okresu pozytywizmu i jego wplywy w Polsce. W: $Z$ historii filozofii pozytywistycznej u Polsce. Ciagłość i przemiany. Red. A. HochfeldowA, B. SKarga. Wrocław 1972, s. 117-118.

2 A. Hochfeldowa: Orientacja nowokrytyczna. W: Filozofia i myśl społeczna $w$ latach 1865-1895. Red. A. HochfeldowA, B. SkArga. Warszawa 1980, s. 70. 
noznaczności lansowanych poglądów filozoficznych. Filozofia nowokrytyczna miała być ewolucjonistyczno-pozytywistyczną teorią bytu, uzupełnioną Kantowską teorią poznania ${ }^{3}$.

Termin „nowokrytycyzm” pojawił się po raz pierwszy w 1901 roku, a więc w czwartym roku wydawania „Przeglądu Filozoficznego”, w tekście Prospekt. Wydawnictwo „Przegladu Filozoficznego”. Filozofia nowokrytyczna; nowokrytycyzm, jak pisała Redakcja, był i być pragnął epistemodyceą, a więc uwierzytelnieniem, usprawiedliwieniem nauki - czyli prościej: teorią nauki. Władysław Weryho w swoim komentarzu ,powrotu do Kanta" wymieniał obok siebie Hermanna von Helmholtza, Wilhelma Wundta, Ernsta Macha, bo rzeczywiście prospekt wspólnym mianem „nowokrytycyzm" obejmował: fenomenalizm, idealizm immanentny, realizm krytyczny, empiriokrytycyzm, uznawał je wszystkie bowiem za kierunki spokrewnione i w zasadzie w jednakowym stopniu odpowiadające współczesnym filozoficznym potrzebom. Niemniej jednak przywołanie haseł nowokrytycyzmu i ewolucjonizmu było opowiedzeniem się „Przeglądu Filozoficznego” po stronie dwóch żywotnych szkół czy kierunków, które według Redakcji pisma miały się wzajemnie uzupełniać i wspólnie oznaczać świadome, niedogmatyczne nawiązanie do Kantowskiej teorii poznania; w teorii tej pytania o aprioryczne i aposterioryczne pierwiastki wiedzy, o to, jak możliwa jest nauka - jak podkreśla to Stanisław Borzym w pracy Panorama polskiej myśli filozoficznej - wysuwały się na czoło zagadnień ${ }^{4}$. Na tej podstawie można twierdzić, że nowokrytycyzm to pojęcie szersze niż neokantyzm i neokantyzm (neokrytycyzm) w sobie mieszczące.

Trzeba jednak stwierdzić, że los nie był szczególnie łaskawy dla przedstawicieli tego nurtu. I to zarówno w czasach im współczesnych, jak i późniejszych. Także dzisiaj nowokrytycyzm jest przedmiotem zainteresowania raczej nielicznych filozofów. Pomimo więc dającej się od jakiegoś czasu zauważyć penetracji polskiej filozofii nowokrytycznej — która niewątpliwie wnosi cenny wkład w rozpoznanie epoki pozytywistycznej w Polsce należy zasygnalizować, że podejmowane eksploracje nie wyczerpują całej złożoności i różnorodności problematyki tego nurtu. Warto przy tym podkreślić, że przedstawiony tu stopień zainteresowania badawczego rodzimych historyków filozofią pozytywistyczną w Polsce nie jest czymś wyjątkowym. Oto Herbert Schnädelbach w 1984 roku napisal we Wprowadzeniu do Filozofii w Niemczech 1831-1933, że jeśli ktoś dzisiaj „,próbuje uprzytomnić sobie historię niemieckojęzycznej filozofii w okresie między niemieckim idealizmem i początkami naszej filozoficznej współczesności, wchodzi

\footnotetext{
3 Ibidem.

4 S. Borzym: Panorama polskiej myśli filozoficznej. Warszawa 1993, s. 59-60.
} 
na teren prawie nieznany" Tezę swoją uzasadniał głównie tym, że w nauczaniu akademickim czas ten traktuje się jako okres schyłku, a nawet upadku „wielkiej filozofii”, której ponowne odrodzenie przypada dopiero na mniej więcej lata dwudzieste XX wieku.

Rzecz dotyczy może przede wszystkim neokantyzmu, który jakkolwiek był wówczas (to znaczy w drugiej połowie XIX wieku) dominującym w praktyce akademickiej kierunkiem, to jednak „osąd historii” skazał jego przedstawicieli albo na zupełne zapomnienie, albo co najwyżej na rolę epigonów lub poprzedników. Właściwie, zdaniem Schnädelbacha, nie znamy przedstawicieli neokantyzmu wcale bezpośrednio, lecz tylko z przypisów do dzieł filozoficznie najsilniej oddziaływujących w początkach ubiegłego stulecia, albo w najlepszym razie jako opozycję, wobec której formułowane były te nowe stanowiska filozoficzne ${ }^{6}$.

Jeszcze gorzej rzecz się przedstawia, jeśli zechcemy z całej orientacji neokantowskiej wyodrębnić ówczesny neokantyzm niemiecki skupiony wokół Historii materializmu Fryderyka Alberta Langego. Wówczas ocena tej orientacji może okazać się druzgocąca. Wystarczy przypomnieć opinię Wilhelma Windelbanda, który sądził, że ówczesny neokantyzm był wyrazem ubóstwa intelektualnego filozofii niemieckiej. Natomiast przyczyną owego ubóstwa, jak stwierdzał Windelband, było dla filozofii w Niemczech, ale oczywiście nie tylko dla filozofii, nastanie „ery pozytywnej”7.

\section{Polska kultura duchowa na przełomie XIX i XX wieku}

Pytanie o stan polskiej kultury duchowej, głównie filozoficznej, w tak rozumianej erze pozytywnej, szczególnie w ostatnich dwóch dziesiątkach lat XIX wieku i początkach XX wieku w Polsce, jest w kontekście filozofii pozytywizmu zasadne, skoro wyrażano wówczas opinie, że kierunki w polskiej kulturze duchowej są właściwie tylko echem kierunków europejskich. Najdobitniej myśl tę wyraził Adam Zieleńczyk, gdy stwierdził, że de facto źródło każdego kierunku filozoficznego w Polsce - a przekonanie to doty-

5 H. Schnädelbach: Filozofia $w$ Niemczech 1831-1933. Przeł. K. Krzemieniowa. Warszawa 1992, s. 13.

${ }^{6}$ Ibidem, s. 13, 14.

7 Opinię Windelbanda z jego pracy pod tytułem Die Philosophie im Deutschen Geistesleben des XIX. Jahrhunderts przytaczam za: A. HochFELDOWA: Neokantyzm okresu pozytywizmu i jego wplywy w Polsce..., s. 115. 
czy także filozofii końca XIX wieku — da się odszukać w kulturze Europy Zachodniej. ${ }^{8}$ I to zdanie jest bez wątpienia słuszne. Nieco dalej autor dodawał, że współczesna filozofia w Polsce nie przedstawia niczego, „co by poza szranki myśli stworzonej gdzie indziej wychodziło"".

Zieleńczyk zresztą w swojej opinii nie był odosobniony. Pominę w tym miejscu oceny tej filozofii czynione przez jej przedstawicieli (oraz ich krytyków), które niewątpliwie miały wpływ na jej późniejsze traktowanie, odwołam się natomiast do poglądów nam współczesnych na ten temat. Okazuje się, że mamy tu do czynienia właściwie z czymś, co można by nazwać opinią powszechną i co chyba najlepiej wyraża się w wypowiedzi Anny Hochfeldowej, że dzisiaj nie da się uniknąc uczucia „pewnego smutku”, kiedy mówi się o polskiej literaturze filozoficznej końca XIX wieku. „Wszędzie był to czas średniej miary, ale ziemia polska okazała się wyjątkowo jałowa" ${ }^{10}$. Autorka - w innym miejscu — dodaje nawet, że „czas ten pozbawiony był dzieł wybitnych, a działalność czynnych w dziedzinie filozofii pisarzy ograniczała się na ogół do informacyjnych i nauczycielskich funkcji"l1.

Można twierdzić, że chociaż wypowiedzi te sformułowane były prawie pół wieku temu, to do dzisiaj niewiele się zmieniło i inne, bardziej pozytywne oceny tamtego czasu są zupełnie pomijane. Wystarczy odwołać się do zamieszczonego w „Prawdzie” z 1894 roku artykułu Ludwika Krzywickiego - skądinąd wybitnego przedstawiciela nauki polskiej, jednego z pierwszych i największych socjologów i etnologów polskich, który scharakteryzował ruch intelektualny lat siedemdziesiątych XIX wieku w Polsce, a jednocześnie podjął próbę oceny tego dorobku epoki pozytywistycznej z nieodległej perspektywy. Krzywicki pisał, że „pozytywiści wyrąbali okienko w naszej ciemnicy, a sił swoich nie żałowali. Jakie zaś światło tamtędy wpadło, nie od nich to już zależało. Było ono przecie tak silne, że sowy swojskie zahuczały"12. I dalej dodawał, że wytworzyła się sytuacja, w której spora część naszych przedstawicieli myśli intelektualnej „nie przyznaje się, co winni pozytywizmowi, jeszcze więcej nawet o tym

8 A. ZieleńczyK: Drogi i bezdroża filozofii polskiej. W: IDEM: Drogi i bezdroża filozofii. Warszawa 1912, s. 205.

9 Ibidem.

10 A. Hochfeldowa: Neokantyzm okresu pozytywizmu i jego wplywy w Polsce..., s. $115,116$.

11 A. Hochfeld: Krytyka systemu Kanta $i$ program nowokrytyczny Mariana Massoniusa. „Archiwum Historii Filozofii i Myśli Społecznej” 1975, T. 21, s. 171. Por. także: B. Skarga, A. Hochfeldowa: Polska myśl filozoficzna w epoce pozytywizmu. W: Filozofia i myśl społeczna w latach 1865-1895. Wybrały, oprac., przypisami opatrzyły A. Hochfeldowa, B. Skarga. Cz. 1. [700 Lat Myśli Polskiej]. Warszawa 1980, s. 98, 99.

12 K.R. Żywicki [L. Krzywicki]: Jeden z pogromców. „Prawda” 1894, nr 41, s. 484. 
nie wie”. A przecież — pisał dalej — „pamiętam ów wpływ, jaki światło sprowadzone wywarło na grono, w którym wzrastałem. Żaden z nas nie był »pozytywistą«, wszyscy jeszcze na tym prądzie wychowaliśmy się. Jak $\mathrm{z}$ orzecha łupinę, tak odrzuciliśmy jego socjologię, lecz wykarmiliśmy się na jądrze - poszanowaniu dla myśli krytycznej i zapale, jaki stamtąd powiał. A sądzę, że jest to rdzeń pozytywizmu i gdyby rzecznicy jego dojrzewali w obecnej chwili, zatrzymaliby równie to jądro; bez tego prądu istniałoby swojskie mieszczaństwo, ale nie byłoby światła europejskiego"13. Zatem — jak podkreślał — pozytywizm to stara, ale „dobra szkoła” myślenia.

Oczywiście Krzywicki nie szczędził pozytywizmowi wielu słów krytyki, potrafił wskazać jego słabości i niedostatki, ale potrafił też docenić wniesiony przez ten prąd wkład w polskie życie naukowe i społeczne. Był bowiem pewny, że pozytywizm dysponował wartościowym zespołem przekonań i idei.

Znacznie bardziej krytyczny w tym czasie wobec pozytywizmu był Henryk Struve. W 1891 roku w zamieszczonym w „Bibliotece Warszawskiej” artykule o symptomatycznym tytule Pozytywizm $i$ zadania krytyczne filozofii napisał, że ,pozytywizm, pomimo wszelkich deklamacji o nauce, pomimo chęci zmonopolizowania nauki na swój wyłączny użytek, już w pierwszych swych zawiązkach nie odpowiadał bynajmniej wymaganiom naukowej ścisłości i krytyki"'14. Autor tej opinii był zatem głęboko przekonany, że pozytywizmowi brak krytycznych podstaw, a więc krytycznej teorii poznania. Przez to zaś filozofia pozytywistyczna nie spełnia - jak to określał - wymagań krytycznej naukowości. Trzeba też zaznaczyć, że swojego zdania o pozytywizmie - jeśli chodzi o tak zwany pierwszy pozytywizm - Struve nie zmienił do końca i przy każdej okazji stwierdzał ów brak krytyczności w pozytywizmie. Można więc na tej podstawie sugerować, że Struve nie zauważał zmian, jakie stopniowo dokonywały się w pozytywizmie polskim już od lat osiemdziesiątych XIX wieku. Tymczasem wczesne i ,upraszczające" pozytywistyczne rozumienie filozofii ustępowało miejsca jej rozumieniu krytycystycznemu - filozofia polska w tym czasie zaczynała wkraczać w nową fazę rozwoju, filozofia pozytywistyczna przekształcała się w postać pozytywistyczno-neokantowską, poprzez nowokrytycyzm, by w końcu — taką mieli nadzieję przedstawiciele krytycznego etapu pozytywizmu w Polsce - przejść w fazę filozofii krytycznej.

Dzisiaj, z perspektywy współczesności, można analizować wady i zalety pozytywizmu, jego słabości i atuty. Epoka pozytywizmu pozostawiła

13 Ibidem.

${ }^{14}$ H. Struve: Pozytywizm i zadania krytyczne filozofii. „Biblioteka Warszawska” 1891, T. 1, s. 17. 
rozmaite przekonania - takie, które warto propagować, i takie, które mają znaczenie jedynie historyczne. Tymczasem wciąż duża jest liczba publikacji, w których traktuje się pozytywizm niezwykle krytycznie, padają nawet skrajne oceny, że przyniósł on ogromnie dużo szkód, a pożytku bardzo niewiele. Stąd już tylko krok do odmówienia temu prądowi wszelkiego sensu, a nawet umieszczenia terminu ,pozytywizm” wśród obraźliwych epitetów. I taki stan rzeczy dotyczy przedstawicieli różnych dziedzin wiedzy, a nawet - jak można sugerować — sporej części polskiego społeczeństwa.

Wydaje się więc, że historycy filozofii potraktowali cały ten okres rozwoju filozofii polskiej rzeczywiście niezbyt łaskawie i że wynika to $\mathrm{w}$ niewielkim uproszczeniu - $\mathrm{z}$ dwóch głównych przyczyn. Pierwsza z nich została już zasygnalizowana. Chodzi o to, że tak zwany pozytywizujący kantyzm, poza niewątpliwie dużą poczytnością dzieła F.A. Langego, nie doczekał się większego zainteresowania i uznania ani w Niemczech, ani w Polsce. Tymczasem prace tak zwanych polskich neokantystów identyfikowane były najczęściej z wpływami tego niemieckiego kierunku.

$\mathrm{Na}$ tę sytuację nakładała się druga, nie mniej ważna przyczyna niskiej oceny pozytywizmu. Mianowicie tak zwana era pozytywistyczna w Polsce widziana była $\mathrm{w}$ dużej mierze przez pryzmat przedstawicieli ,pozytywizmu warszawskiego". O nich zaś ugruntowaną opinię najlepiej i krótko przedstawiła Barbara Skarga, która stwierdziła, że przy lekturze tekstów nawet najwybitniejszych przedstawicieli „młodej prasy” może właściwie każdego czytelnika „ogarnąć nuda”. „Są to teksty pod względem zawartości teoretycznej słabe, pełne niekonsekwencji, nieraz rzeczowych błędów. Młodzieńcza śmiałość nie mogła pokryć dyletantyzmu"15.

Nawet wówczas, gdy wyodrębniano z pozytywizmu tak zwaną drugą fazę, a jej przedstawicieli nazywano drugim pokoleniem polskich pozytywistów, generalna opinia o tym prądzie właściwie się nie zmieniała. Bo oto Tadeusz Czeżowski w 1947 roku w swoim Wspomnieniu pośmiertnym po śmierci Mariana Massoniusa zalicza go do tak zwanego pozytywizmu warszawskiego $^{16}$.

Z pewnością Czeżowski rozumiał wówczas ten termin szerzej, a nie tylko jako „młodą prasę", ale nie zmienia to postaci rzeczy — dominujący w latach osiemdziesiątych i dziewięćdziesiątych XIX wieku ruch filozoficzny w Polsce potraktował co najwyżej jako swoistą formę epoki pozytywizmu, nie zaś choćby jako pozytywistycznie rozumiany krytycyzm. Zatem podjęcie problematyki teoriopoznawczej uznał, jak można sugerować,

15 B. Skarga: O kilku problemach pozytywizmu polskiego. W: Polska myśl filozoficzna i społeczna. Red. B. Skarga. T. 2. Warszawa 1975, s. 13, 14.

16 T. Czeżowski: Wspomnienie pośmiertne. „Przegląd Filozoficzny” 1947, z. 1/4, s. 149. 
zresztą znów w zgodzie z przyjętymi i panującymi dotąd na ten temat zapatrywaniami, za powszechne znamię pozytywizmu.

Gdyby sugerowany wniosek był trafny, to wówczas rzeczywiście uzasadnione byłoby postawienie pytania, czy w ogóle można mówić o neokantyzmie polskim. W szczególności zaś, czy za jakąś neokantowską ,wersję" można uznać filozofię nowokrytyczną z końca XIX wieku w Polsce, reprezentowaną przez de facto dwóch najwybitniejszych filozofów tego nurtu, a mianowicie przez Adama Mahrburga i Mariana Massoniusa. Charakterystyczne jest, że dzięki między innymi tym myślicielom zaczął dochodzić do głosu program „filozofii krytycznej” w polskiej myśli filozoficznej.

Znajomość filozofii Kanta czy w ogóle zainteresowanie jego filozofią stawały się po koniec XIX stulecia faktem. Powoli narastała potrzeba odpowiedzi na pytanie o znaczenie myśli Kanta dla współczesnej filozofii. Podejmowano także próby określenia stosunku ówczesnej filozofii polskiej do myśli Kanta i wpływów wczesnego neokantyzmu w Polsce (nie ograniczano się przy tym tylko do tej postaci wpływu, jaką mu nadał autor Historii filozofii materialistycznej $i$ jej znaczenia w teraźniejszości).

Faktem było także - jak pisze Skarga - że czas ten charakteryzował się skierowaniem uwagi filozofów polskich na teorię poznania. Dodaje również, że po 1880 roku artykuły o Kancie posypały się niczym z rogu obfitości. Pisali o Kancie tacy przedstawiciele filozofii polskiej, jak Władysław Mieczysław Kozłowski, Mieczysław Kaufmann, Seweryn Smolikowski, Maurycy Straszewski, Witold Rubczyński czy wreszcie Marian Massonius, Adam Mahrburg i Mścisław Wartenberg.

Znamienną opinię o filozofii Kanta — w dużej mierze podsumowującą próbę krytycystycznej reorientacji pozytywistycznej myśli polskiej wypowiedział Mahrburg. Otóż, jak stwierdził, nie ulega wątpliwości, że „Wszyscy wybitniejsi filozofowie naszych czasów przeszli szkołę Kanta i wszyscy czują na sobie wpływ jego myśli potężnej”'17. A to z kolei — jak mógłby dalej dodać ten filozof — niewątpliwie miało wpływ między innymi na różnego rodzaju spory i polemiki między przedstawicielami rozmaitych orientacji filozoficznych.

Tymczasem w szeroko rozumianej literaturze filozoficznej można spotkać się ze stwierdzeniami, że spory czy choćby tylko nieporozumienia terminologiczno-semantyczne, mimo iż na swój sposób interesujące, wydają się jednak dość jałowe, a ponadto jeszcze często niekonkluzywne.

Otóż można sugerować, że w przypadku sporu, który jest tematem tego artykułu chyba tak do końca nie jest. Chodzi o to, że przyjrzenie się bliżej

17 A. Mahrburg: Emanuel Kant. W: Pisma filozoficzne Adama Mahrburga. Red. W. SPAsowsKi. T. 2. Warszawa 1914, s. 307. 
nieporozumieniom $\mathrm{w}$ sprawie nowokrytycyzmu może prowadzić do interesujących wniosków, w kontekście przede wszystkim otwierania się na nowe czasy filozofów polskich, a więc pojawiania się w ich poglądach różnych wątków, w tym obcych pozytywistycznemu sposobowi myślenia.

\section{Zagadnienie nowokrytycyzmu w polemice Kobyłeckiego z Massoniusem}

Dyskusja, jaka zaistniała między przedstawicielami dwóch różnych tendencji w rozwoju filozofii polskiej, rozpoczęła się — jak można twierdzić w 1906 roku, a związana była z artykułem księdza Stanisława Kobyłeckiego zatytułowanym Warszawska filozofia nowokrytyczna. Kobyłecki omówił w tym tekście prospekt „Przeglądu Filozoficznego” zatytułowany Filozofia nowokrytyczna i niewątpliwie przedstawił w swoim artykule wiele ciekawych spostrzeżeń, szczególnie właśnie z punktu widzenia zaznaczających się tendencji $\mathrm{w}$ rozwoju polskiej myśli filozoficznej przełomu XIX i XX wieku. A trzeba przy tej okazji wspomnieć, że - jak pisze Ludwik Nowak - Kobyłecki był jednym z bardziej samodzielnych i oryginalnych myślicieli polskich, zajmującym odrębne stanowisko w filozofii, które nazywał relacjonizmem ${ }^{18}$.

Otóż Warszawska filozofia nowokrytyczna to tekst jednoznacznie krytyczny, w którym Kobyłecki, jako uczeń Wundta i późniejszy profesor psychologii eksperymentalnej na Wydziale Teologicznym Uniwersytetu Warszawskiego, surowo ocenił nowokrytycyzm. Źle ocenił przede wszystkim sam projekt wydania Filozofii nowokrytycznej (napisał, że „tak już bardzo zasłużona na polu fillozoficznego ruchu w Polsce redakcja »Przeglądu Filozoficznego« mniej szczęśliwą miała rękę, dając nakład na to nowe wydawnictwo" ${ }^{19}$ ), jak również jego treść, to znaczy dobór artykułów oraz przedmowę autorstwa Massoniusa.

Wydaje się, że krytyczne stanowisko Kobyłeckiego można sprowadzić do przynajmniej pięciu punktów.

18 L. NowaK: Filozoficzno-logiczne poglady Stanisława Kobyłeckiego. „Studia Philosophiae Christianae" 1967, nr 3/1, s. 111.

19 S. КовүŁескі: Warszawska filozofia nowokrytyczna. „Przegląd Powszechny” 1906, T. 90 , s. 42 . 
Po pierwsze - Kobyłecki wyraził ogromne oburzenie, że wydawca Filozofii nowokrytycznej — Redakcja „Przeglądu Filozoficznego” — zrobił z niemieckiego czasopisma wychodzącego w Lipsku (założonego w 1877 roku przez Richarda Avenariusa, do dzisiaj wydawanego pod tytułem: „Vierteljahrsschrift für wissenschaftliche Philosophie und Soziologie”) organ jednolitej szkoły i szkołę tę nazwał filozofią nowokrytyczną.

Po drugie - zdaniem Kobyłeckiego autorzy pomieszczeni w polskim przekładzie tekstów z tego pisma zostali „otaksowani” jako przedstawiciele neokantyzmu, z których co najwyżej jeden, Vaihinger, jest neokrytykiem w zwykłym rozumieniu tego słowa ${ }^{20}$.

Po trzecie - autor Warszawskiej filozofii nowokrytycznej był zbulwersowany taką formą popularyzacji nauk i filozofii, forma ta bowiem powoduje u nieprofesjonalistów powierzchowność i - jak to określał — „wzmacnia skłonność do blagowania"21.

Po czwarte - poddał krytyce Przedmowe Massoniusa; stwierdził, że być może autor Przedmowy przedstawił własne stanowisko, a obok niewielu uwag trafnych zamieścił szereg mniej trafnych albo całkiem błędnych; Kobyłecki nawiązywał tutaj — jak można sądzić - do niezrozumiałych jego zdaniem wyjaśnień dotyczących nowokrytycyzmu, a także metafizyki.

Po piąte - nie mógł pogodzić się z głoszoną przez Massoniusa tezą, że sferę poznania należy radykalnie oddzielać od sfery wiary i nie podejmować nawet prób jakiegokolwiek godzenia nauki i religii, że takie próby porozumienia są niemożliwe, a nawet zupełnie niepotrzebne. Pogląd Massoniusa, że nauka i religia nigdy i nigdzie nie mówią o tych samych przedmiotach, a więc nigdy i nigdzie nie mogą sobie zaprzeczać ${ }^{22}$, był dla Kobyłeckiego nie do przyjęcia.

W kontekście sporu Kobyłeckiego z Massoniusem dotyczącego nowokrytycyzmu interesujące wydają się cztery pierwsze punkty.

Jeśli chodzi o pierwszy punkt, to już tytuł tego wydawnictwa „Przeglądu Filozoficznego", zdaniem Kobyłeckiego, nie tyle jest niefortunny, ile prze-

20 Ibidem, s. 44.

${ }^{21}$ Ibidem, s. 46.

${ }^{22}$ M. Massonius: Agnostycyzm. „Przegląd Filozoficzny” 1904, z. 2, s. 161. Trzeba także dodać, że Massonius był człowiekiem głęboko wierzącym i do końca życia takim pozostał. Pisze o tym Czeżowski, a widać to zwłaszcza w listach do Zdziechowskiego, którego Massonius usiłował w tym względzie ,podtrzymać na duchu”. Dlatego bardzo trafnie — jak się wydaje — przy okazji omawiania filozofii wileńskiej Jadacki sugeruje, że również z tego powodu Massonius znakomicie mieścił się w wileńskim środowisku naukowym (w czasie, gdy był profesorem Uniwersytetu Wileńskiego). Tam bowiem „na ogół nie tylko uznawano niezbędność wiary, ale i ceniono wartości religijne”. Por. J.J. JADACKI: Rzut oka na cztery wieki filozofii wileńskiej. W: Filozofia na Uniwersytecie Wileńskim. Red. R. JADCZAK, J. PAWLAK. Toruń 1997, s. 14. 
de wszystkim zupełnie mylący, wprowadza w błąd czytelników pisma, a zwłaszcza młodych ludzi zainteresowanych obrazem współczesnej filozofii. Kobyłecki ujawniał, że pytali go oni, co myśli o neokrytycyzmie, szczególnie w odniesieniu do Awenariusa czy Wundta. Ponadto Kobyłecki tłumaczy Massoniusowi, dlaczego tego niemieckiego czasopisma filozoficznego nie można traktować jako organu żadnej szkoły, a tym bardziej organu filozofii neokrytycznej ${ }^{23}$. Argumentów, notabene niektórych trafnych, podaje bardzo wiele, by w końcu przedstawić „właściwe” rozumienie neokrytycyzmu czy neokantyzmu lub „neokancyanizmu” i napisać, że „Przez neokrytycyzm czy neokantyzm lub neokancyanizm rozumie się powszechnie ten kierunek najnowszej filozofii, który pod hasłem »zwrotu do Kanta« nie inny punkt wyjścia obrał sobie do badań filozoficznych jak założenia »Krytyki czystego rozumu«. Kto sobie wybiera inny punkt wyjścia, inne stanowisko zajmuje w rozważaniach swych filozoficznych, ten nie jest neokrytykiem" ${ }^{24}$.

To nieporozumienie związane $\mathrm{z}$ tytułem Kobyłecki traktuje bardzo poważnie, zastanawia się nawet nad tym, czy nie lepiej byłoby użyć nazwy "filozofia naukowa", a w końcu dochodzi do wniosku, że najmniej szkody potencjalnemu czytelnikowi wyrządziłaby nazwa „wybór niektórych artykułów" z tego niemieckiego czasopisma. Postuluje jednocześnie, by ten „wybór” opatrzony był krytycznym komentarzem naukowym o autorze przetłumaczonego artykułu, przedstawieniem jego dorobku naukowego oraz charakterystyką zajmowanego przez autora stanowiska filozoficznego ${ }^{25}$.

Wywód przedstawiony w tej kwestii przez Kobyłeckiego może jednak nieco dziwić, i to z kilku powodów. Otóż miał ksiądz Kobyłecki znakomite wykształcenie, z całą pewnością najbardziej gruntowne wykształcenie naukowe spośród ówczesnych filozofów związanych z tomizmem - studiował filozofię w szkołach jezuickich w Tarnopolu (1887-1890) i Krakowie (1890-1894), a następnie filozofię, fizykę i matematykę na Wydziale Filozoficznym Uniwersytetu Jagiellońskiego (1890-1893) oraz, równocześnie, teologię w szkole jezuickiej w Krakowie. W latach 1901-1905 studiował psychologię w Lipsku oraz matematykę i fizykę we Fryburgu Bryzgowijskim oraz w Getyndze. Był także kierownikiem jednego z oddziałów w pracowni psychologii eksperymentalnej Wundta, u którego się zresztą doktoryzował w Getyndze w 1905 roku.

Już tylko te fakty wskazują na to, że Kobyłecki był znakomicie zorientowany w ówczesnych nurtach filozofii i psychologii. Zresztą podobnego zorientowania domagał się także od swoich uczniów, dlatego obligował ich do słuchania wykładów z logiki matematycznej, matematyki, a nawet przy-

\footnotetext{
23 S. KobYŁecki: Warszawska filozofia nowokrytyczna..., s. 43.

24 Ibidem, s. 45.

25 Ibidem, s. 46.
} 
rody. Doskonale również musiał wiedział - co trzeba zasugerować - że bardzo różnie przebiegała recepcja filozofii Kanta w Polsce, w tym to, jaką linię programową przyjął Weryho w „Przeglądzie Filozoficznym”26, którego Kobyłecki był współpracownikiem. Jako uzasadnienie tego stwierdzenia może posłużyć na przykład fakt, że praca tego filozofa, którą zgłosił on w pierwszym ogłoszonym przez „Przegląd” konkursie, została - jak to określił Weryho - odznaczona (konkurs ten został rozstrzygnięty w 1906 roku). Trudno zatem przypuszczać, że Kobyłecki nie orientował się w przyjętej przez pismo linii programowej, omówionej przez Weryhę w 1. zeszycie pisma (1897/1898) - w Słowie wstępnym - oraz zamieszczonym zaraz po nim artykule Adama Mahrburga pod tytułem Co to jest nauka? ${ }^{27}$, znakomicie uzasadniającym tę linię programową ${ }^{28}$. Również w tym 1. zeszycie Kazimierz Twardowski w dziale Przegląd czasopism zamieścił omówienie „Vierteljahrsschrift für wissenschaftliche Philosophie”, w którym poddał analizie krytycznej kilka wybranych artykułów z 1 . i 2. zeszytu tego kwartalnika za 1897 rok $^{29}$. Ponadto w „Przeglądzie Filozoficznym” z 1901 roku ukazał się Prospekt. Wydawnictwo „Przegladu Filozoficznego”. Filozofia nowokrytyczna. Jego autor, Mahrburg, bardzo dokładnie wyjaśnił, jakie założono cele, dlaczego Redakcja zdecydowała się na sięgnięcie do tego niemieckiego czasopisma, jakie kryteria decydowały o wyborze artykułów (w tej kwestii Mahrburg wskazywał siebie jako osobę dokonującą ich wyboru oraz ostatecznej redakcji przekładów), ale przede wszystkim na początku napisał, co rozumie przez nowokrytycyzm: „Przez nowokrytycyzm, biorąc rzecz najogólniej, rozumiemy kierunek filozoficzny, który przyjmuje za historyczny punkt wyjścia teorię poznania Kanta, usiłuje oddzielić w wiedzy pierwiastki aprioryczne od aposteriorycznych i rozwiązać pytanie - jakim sposobem, przy jakich warunkach nauka, dana jako fakt i rozważana jako ideał, jest możliwą" ${ }^{30}$. Dalej stwierdzał, że ,nowokrytycyzm we wszystkich postaciach swoich, jak fenomenalizm, idealizm immanentny, realizm krytyczny, krytycyzm empiryczny — stoi dziś na czele ruchu filozoficznego nie tylko w Niemczech, lecz w Anglii, Francji, Włoszech, Danii” ${ }^{31}$. Podkreślał też zasługi tego niemieckiego pisma: „odegrało ono bardzo poważną rolę w rozwoju nowokrytycyzmu w Niemczech i pośrednio

26 W. Weryho: Stowo wstępne. „Przegląd Filozoficzny” 1897/1898, R. 1, z. 1, s. VI.

27 A. Mahrburg: Co to jest nauka? „Przegląd Filozoficzny” 1897/1898, R. 1, z. 1, s. 3.

28 W. Weryho: Stowo wstepne..., s. VI.

29 K. Twardowski: [w dziale: Przegląd czasopism]. „Przegląd Filozoficzny” 1897/1898, R. 1, z. 1, s. 144 .

30 [A. Mahrburg:] Prospekt. Wydawnictwa „Przegladu Filozoficznego”. Filozofia nowokrytyczna. „Przegląd Filozoficzny” 1901, R. 4, z. 4, s. I.

31 Ibidem, s. II. 
oddziałało na filozofię współczesną w ogóle. W ciągu dwudziestoletniego kierownictwa Avenariusa organ ten stał na czele i najlepiej obrazował rozwój filozofii nowokrytycznej w okresie od roku 1877 do 1896 włącznie. Po śmierci Avenariusa pod nową redakcją zmienił już swój charakter, z ujmą dla naukowej swojej wartości" ${ }^{32}$.

Przedstawione stanowisko Mahrburga w pełni akceptował Massonius, po rezygnacji Mahrburga bowiem bez wahania podjął się dokończenia tego polskiego projektu bez dokonywania jakichkolwiek zmian w zaakceptowanych już do druku artykułach, a Redakcja „Przeglądu Filozoficznego” w 1903 roku z satysfakcją zawiadamiała o tym na swoich łamach: „Z powodu braku czasu p. Adam Mahrburg zrzekł się kierownictwa wydawanej przy »Przeglądzie Filozoficznym« Filozofii Nowokrytycznej, a jego miejsce zajął Dr Marian Massonius. Jesteśmy przekonani, że odtąd Filozofia Nowokrytyczna będzie wychodziła w szybszym tempie"33. I rzeczywiście, po dwóch latach ukazało się już pełne wydanie tego projektu wydawniczego „Przeglądu”, zaopatrzone w Przedmowę Massoniusa ${ }^{34}$.

W tej Przedmowie Massonius, podobnie jak wcześniej Mahrburg, wyjaśnił, co rozumie przez nowokrytycyzm. „Filozofią nowokrytyczną - pisał — nazywamy kierunek filozoficzny, który ukształtował się w siódmym i ósmym dziesiątku lat ubiegłego stulecia, a który za obowiązujący punkt wyjścia dla dalszych badań filozoficznych uznał wyniki Krytyki czystego rozumu Kanta"35. Przy czym jasne jest, że nie rozumiał przez to pełnej i pozbawionej wątpliwości akceptacji kantowskiego idealizmu transcendentalnego. Wynikami tegoż były postawione przez Kanta zagadnienia, które traktował jako podstawowe i których rozwiązanie, albo wykazanie nierozwiązalności, miało stanowić konieczny warunek naukowego filozofowania. Wśród tych problemów zasadnicze jest zagadnienie obiektywności poznania.

$\mathrm{W}$ ten sposób wyjaśnia się, przynajmniej częściowo, drugi zarzut Kobyłeckiego (ujęty w przedstawionym przeze mnie drugim punkcie), mianowicie ten, że autorzy pomieszczeni w polskim przekładzie niemieckiego pisma zostali „otaksowani” jako przedstawiciele neokantyzmu. Bardzo znamienne są tu dwa fakty. Pierwszy to ten, że Kobyłecki całkowicie utożsamia $\mathrm{z}$ sobą te dwa nurty filozoficzne, a mianowicie neokantyzm i nowokrytycyzm. Można by więc odnieść wrażenie, że poza najbliższymi mu stanowiskami filozoficznymi wszystkie inne ten autor zaliczał do neokantowskich. Oczywiście zarówno Mahrburg i Massonius, jak i Kobyłecki

32 Ibidem, s. III.

33 „Przegląd Filozoficzny” 1903, R. 6, z. 2, s. 120.

34 Filozofia nowokrytyczna. [Wydawnictwo „Przeglądu Filozoficznego”]. Warszawa 1905.

35 M. Massonius: Przedmowa. W: Filozofia nowokrytyczna..., s. I. 
mieli zapewne świadomość całej złożoności sytuacji, w którą od początku powstania uwikłany był neokantyzm. Można też domniemywać, że znakomicie rozumieli, iż w nurcie tym nie chodziło o wierne naśladowanie Kanta, ale raczej o przyjęcie jego ogólnego stanowiska czy też ogólnej postawy i podjęcie próby podążania drogami, które Kant wytyczył. Jeśli brano pod uwagę takie właśnie rozumowanie, to wielu filozofów mogło zostać określonych mianem neokantystów, przy czym stopień ich przynależności do tego nurtu był bardzo różny. W opublikowanym tomie pod tytułem Filozofia nowokrytyczna jednak zupełnie nie o to chodziło. Inne cele stawiali sobie Weryho, a przede wszystkim Mahrburg oraz Massonius.

Redaktor "Przeglądu Filozoficznego" domagał się przede wszystkim, by filozofię uprawiać w sposób „ścisły” i „naukowy”. Miała się ona opierać w swoich dociekaniach na wynikach nauk szczegółowych, przy jednoczesnej krytycznej refleksji epistemologicznej. „Opierając się na wynikach nauk specjalnych - pisał Weryho - i jednocześnie na rozbiorze zasadniczych procesów poznania, filozofia wytwarza ogólne zasady i wskazówki, które za podstawę dalszego postępu tychże nauk specjalnych służąa" ${ }^{\prime 3}$. A ponadto, co nie mniej ważne, dodawał, że filozofia dzięki porządkowaniu pewnych kategorii pojęciowych oraz prezentowaniu różnych rozwiązań, a tym samym wyrabianiu krytycznego nastawienia, może — jego zdaniem — stanowić podstawę formułowania własnych, samodzielnych przekonań, i to najlepiej opartych na indywidualnie przeprowadzanych badaniach. Rzeczywiście więc chodziło o to, aby ten tom zawierał rozprawy oryginalne, w których wyraziła się — jak pisał Mahrburg w Prospekcie w 1901 roku — ,żywa praca twórcza głównych przedstawicieli nowokrytycyzmu"37, bo tylko w ten sposób osiągnięte zostaną dwa cele, a mianowicie czytelnik polski będzie miał możliwość zapoznania się z głównym organem nowokrytycyzmu, przy czym niezatarte pozostaną odrębności indywidualne i rzeczywista kolej rozwoju historycznego, a także $\mathrm{w}$ obręb naszego myślenia filozoficznego wprowadzony zostanie ,pierwiastek”, którego po prostu brakuje. Mahrburg bowiem, podobnie jak Massonius, był przekonany, że to właśnie czasopisma odgrywają rolę pierwszoplanową w warsztacie pracy naukowej każdego uczonego.

Jeśli chodzi o dobór artykułów do Filozofii nowokrytycznej, to kryterium było jasne - artykuły musiały spełniać rygory naukowości, a autorzy powinni być zaliczani do najwybitniejszych ówczesnych umysłów - uczonych i filozofów. Jako przykład można przywołać Wundta, który Mahrburgowi imponował nie tyle swoją filozofią, ile wszechstronną wiedzą, zmysłem konstrukcyjnym, organizacyjnym i klasyfikatorskim. „W Wundcie — pi-

36 W. WeRYHO: Stowo wstępne..., s. II.

[A. Mahrburg:] Prospekt..., s. III. 
sał Mahrburg w 1903 roku w „Książce” — należy starannie odróżniać uczonego o nader rozległej, wielostronnej i gruntownej wiedzy od filozofa-doktrynera. Jako uczony jest on nie tylko obyty z metodami doświadczalnymi i eksperymentalnymi, lecz jest twórcą i mistrzem, zwłaszcza w logice i w psychologii doświadczalnej”38. Nieco dalej dodawał jednak, że „Jego [Wundta - B.S.] »System filozofii« sprawia przygnębiające wrażenie wobec dowolności, z jaką wypełnia wszelkie luki twierdzeniami nieudowodnionymi, zaokrągla całość ogólnikami, byleby tylko nie pozostawić żadnej dobrze czy źle pojętej zagadki świata bez rozwiązania" ${ }^{39}$. Podobnie było z innymi wielkimi uczonymi, których pomysły i poglądy — o czym byli przekonani redaktorzy Filozofii nowokrytycznej — trzeba zawsze przeanalizować i przemyśleć.

Jeśli chodzi o trzeci punkt wśród zarzutów Kobyłeckiego, a więc formę popularyzacji nauk i filozofii, to rzeczywiście nie jest to zadanie łatwe, chyba nawet we współczesnym świecie. Projekt wydania Filozofii nowokrytycznej nie miał jednak na celu popularyzacji, a na pewno nie przede wszystkim popularyzacji nauki i filozofii, bo temu miał służyć na przykład Poradnik dla samouków, wydawany w latach 1898-1932 przez Aleksandra Heflicha i Stanisława Michalskiego oraz fundatora - Kasę im. Józefa Mianowskiego. A trzeba dodać, że było to osobliwe, niemające precedensu przedsięwzięcie edukacyjno-edytorskie, które stało się możliwe dlatego, że narastała wówczas wśród Polaków w kraju wola uczenia się, ponadto byli wybitni uczeni, ale nie było szkół, w których mogliby wykładać po polsku ${ }^{40}$.

Diagnoza, jaką przedstawił w 1897 roku Weryho ${ }^{41}$, przestawała być aktualna, sytuacja $\mathrm{w}$ odniesieniu do stanu nauki w Polsce zaczęła się rzeczywiście systematycznie polepszać i powiększał się krąg czytelników, którzy już nie chcieli zadowalać się „blagą naukową”, jak to chyba pierwszy określił Franciszek Krupiński. Już w roku następnym Struve pisał, że „i u nas zaczyna się wytwarzać koło czytelników nie zadowalających się ani samą literaturą nadobną, ani powierzchowną popularyzacją zdobyczy współczesnej nauki" ${ }^{\prime 2}$, i z nadzieją dodawał, że być może on też „przyczyni się do ukształtowania naszego życia umysłowego, do postępu u nas poważnych badań nad filozofią, tak niezbędnych dla każdego narodu,

38 A. Mahrburg: Filozofia, psychologia, estetyka, etyka. „Książka” 1903, R. 3, nr 8, s. 276.

39 Ibidem, s. 277.

${ }^{40}$ W tym kontekście należy także wspomnieć Uniwersytet Latający, na którym Mahrburg wykładał filozofię.

${ }^{41}$ W. Weryho: Stowo wstępne..., s. II-III.

42 H. Struve: Wstęp krytyczny do filozofii, czyli rozbiór zasadniczych pojęć o filozofii. Wyd. 2. Warszawa 1898, s. VII. 
pragnącego przyjąć czynny udział w rozwoju cywilizacyjnym ludzkości’³. I temu właśnie - najogólniej mówiąc - miało służyć wydanie Filozofii nowokrytycznej.

Wreszcie ostatni, czwarty punkt dotyczący niejasności związanych z pojęciem nowokrytycyzmu. Otóż i wtedy, i dzisiaj różnie rozumie się pojęcie „nowokrytycyzm”. O tym, jak wyjaśniali ten nurt filozoficzny Mahrburg i Massonius, była już mowa. Takie rozumienie nowokrytycyzmu akceptował także Weryho. Natomiast nie akceptował takiego pojmowania terminu „nowokrytycym” Kobyłecki, który neokantyzm i nowokrytycyzm traktował synonimicznie. Późniejsi historycy filozofii albo utożsamiali nowokrytycyzm z neokantyzmem - i wtedy termin „nowokrytycyzm” mógł oznaczać wszystkie odmiany stanowisk neokantowskich - albo rozumieli go w sposób nieco zawężony, a właściwie wprost odniesiony do warunków polskich, przy czym na przykład wiązali go tylko z jedną postacią neokantyzmu, a mianowicie z pierwszym neokantyzmem niemieckim w wersji F.A. Langego i jego szkoły — wtedy nowokrytycyzm zbliżał się w swoich podstawowych treściach do krytycyzmu pozytywistycznego.

Najtrafniej chyba współczesne rozumienie nowokrytycyzmu przedstawił Jerzy Kojkoł, nawiązujący zresztą do interpretacji Hochfeldowej, który napisał, że ta „formuła" nie odpowiadała pojęciu „neokantyzm” rozumianemu w historii filozofii europejskiej jako określenie na różnorodne odmiany stanowisk neokantowskich. „Polski nowokrytycyzm był związany przede wszystkim z naturalistyczno-ewolucjonistyczną wykładnią kantyzmu, która mogła być odczytywana jako stanowisko zbieżne z pewnymi tezami pozytywistycznymi. [...] Znamienną cechą tego kierunku było kontynuowanie tradycji zarówno kantyzmu, jak i wszystkich współczesnych nurtów filozofii pozytywistycznej, od empiriokrytycyzmu po fizykalizm, oraz korzystanie $\mathrm{z}$ metodologicznych treści właściwych nowoczesnemu przyrodoznawstwu. Rezonans tak szeroko pojmowanego prądu teoretycznego był dość duży, często sprowadzał się on jednak do akceptowania pojedynczych tez tego stanowiska”44. I dalej: „Ze względu na nieokreśloność, fragmentaryczność i powierzchowność tych filozoficznych deklaracji, nowokrytycyzm można traktować jako pewną myślową orientację odbiegającą znacznie od teoretycznej jednolitości i jednoznaczności lansowanych poglądów filozoficznych" ${ }^{\text {45 }}$.

43 Ibidem.

44 J. KoJKol: Immanuel Kant w Polsce - wybrane problemy recepcji przełomu XIX i XX wieku. „Studia z Historii Filozofii” 2015, vol. 6, nr 1, s. 120. https://doi.org/10.12775/ szhf.2015.008.

45 Ibidem. 
To ostatnie stwierdzenie wydaje się dotknięciem sedna zagadnienia. Bo rzeczywiście w nowokrytycyzmie chodziło - jak to ujął zwięźle Struve, gdy krytykował pozytywizm w artykule Pozytywizm i zadania krytyczne filozofii - o przestrzeganie „krytycznej naukowości”46. Oczywiście podobne poglądy wyrażało wielu filozofów polskich tego czasu - od Aleksandra Świętochowskiego i jego „filozofii krytyczno-naukowej” poczynając, przez wspomnianego Struvego, a także Maurycego Straszewskiego, domagającego się w każdej kwestii krytycznych badań naukowych, Władysława Weryhę, który stawiał tylko na „ścisłość” i „,naukowość” (tu można by wymieniać i innych filozofów), na Massoniusie i Mahrburgu kończąc, nie zapominając przy tym o Kobyłeckim, który domagał się w pracy Postulaty psychologii doświadczalnej, aby wszystkie zagadnienia były rozpatrywane krytycznie i ściśle naukowo ${ }^{47}$.

\section{Naukowość i krytycyzm jako filary pozytywnego typu myślenia polskiego}

Uwzględnienie przedstawionej perspektywy rozumienia pozwala być bliżej głównego i właściwego sensu zawartego w formule nowokrytycyzmu. To nie miał być żaden tak zwany izm, bo jak pisał Mahrburg w 1903 roku w artykule Pozytywizm $w$ opałach reakcji: „Najtrudniejsza sprawa, jak zawsze, z izmami, szczególnie u nas, gdzie one zawsze bywały i bywają tylko chwilowymi gośćmi, a, pomimo znanej gościnności naszej, losy każdego z nich zależą zazwyczaj od przybycia nowego gościa z zachodu, z dobrymi, oczywiście, rekomendacjami’48. Przeciwnie, chodziło o wytyczenie linii dalszego rozwoju nauce i filozofii w Polsce, którą to linię powinna cechować przede wszystkim „naukowość” i krytycyzm. Przy czym - jak podkreślał Mahrburg — rękojmią naukowości wiedzy musi być uświadomiona i uznana metoda zdobycia lub skonstruowania tejże wiedzy, „krytycyzm” zaś — rozumiany wówczas bardzo szeroko i być może nawet ogólnikowo odnosił się w wyższym stopniu do ogólnej refleksji teoriopoznawczej niż do rzeczywistej kontynuacji myśli Kanta. I dopiero idąc tą drogą, filozofowie polscy mogli wypracować własne, oryginalne poglądy, a filozofia pol-

46 H. Struve: Pozytywizm i zadania krytyczne filozofii..., s. 15-16.

47 S. KobyŁecki: Postulaty psychologii doświadczalnej. Kraków 1906, s. 44.

48 A. Mahrburg: Pozytywizm w opałach reakcji. „Ogniwo” 1903, nr 5, s. 107. 
ska - jak miał nadzieję Massonius — mogła zacząć wkraczać w „epokę filozofii naukowej".

Nowokrytycyzm był więc pewnym projektem. Z jednej strony widać już było, że nauka powoli zaczęła być w stanie dokonywać krytyki samej siebie (chociaż dalej refleksja filozoficzna była nauce niezbędna jako postać świadomości metodologicznej), a pojęcie „naukowy” zostało wyzwolone z wąskich ryzów pozytywistycznej interpretacji.

$\mathrm{Z}$ drugiej strony $\mathrm{w}$ takim projekcie mogły pomieścić się różne stanowiska filozoficzne, byleby spełniały wymogi „naukowości” i „krytyczności”, a zatem w nim również mieściła się koncepcja „filozofii krytycznej” Massoniusa, której najogólniejszym, ale i najważniejszym zadaniem miało być badanie i wyświetlanie kwestii teoretycznych, krytyczne zdawanie sprawy z ich treści i wartości naukowej. Na tej podstawie można twierdzić, że w opinii Massoniusa filozofia, by miała wartość poznawczą, ma jedynie systematycznie i metodycznie rzeczywistość objaśniać, a nie wymyślać ją czy stwarzać, czyli krócej: filozof nie jest twórcą, tylko odkrywcą. Bardzo celnie - jak można sugerować za Massoniusem — ujął tę myśl Mahrburg W zwięzłej wypowiedzi: „wymyślić świata niepodobna, trzeba go poznać”49.

\section{Bibliografia}

Borzym S.: Panorama polskiej myśli filozoficznej. Warszawa 1993.

Czeżowski T.: Wspomnienie pośmiertne. „Przegląd Filozoficzny” 1947, z. 1/4.

Filozofia na Uniwersytecie Wileńskim. Red. R. JADCZaK, J. PaWLak. Toruń 1997.

Filozofia nowokrytyczna. [Wydawnictwo „Przeglądu Filozoficznego”]. Warszawa 1905.

HochFeld A.: Krytyka systemu Kanta $i$ program nowokrytyczny Mariana Massoniusa. „Archiwum Historii Filozofii i Myśli Społecznej” 1975, T. 21.

Hochfeldowa A.: Neokantyzm okresu pozytywizmu i jego wptywy w Polsce.

W: Z historii filozofii pozytywistycznej w Polsce. Ciagłość i przemiany. Red.

A. Hochfeldowa, B. Skarga. Wrocław 1972.

Hochreldowa A.: Orientacja nowokrytyczna. W: Filozofia i myśl społeczna w latach 1865-1895. Red. A. Hochfeldowa, B. SkARgA. Warszawa 1980.

JADACKI J.J.: Rzut oka na cztery wieki filozofii wileńskiej. W: Filozofia na Uniwersytecie Wileńskim. Red. R. JADCZaK, J. PaWlaK. Toruń 1997.

49 Cyt. za: M. Massonius: Mahrburg jako uczony. „Przegląd Filozoficzny” 1914, R. 17 , z. 1 , s. 83 . 
KobyŁecki S.: Postulaty psychologii doświadczalnej. Kraków 1906.

KobyŁecki S.: Warszawska filozofia nowokrytyczna. „Przegląd Powszechny” 1906, T. 90.

Koנкоц J.: Immanuel Kant $w$ Polsce - wybrane problemy recepcji przełomu $X I X$ i XX wieku. „Studia z Historii Filozofii” 2015, vol. 6, nr 1. https://doi. org/10.12775/szhf.2015.008.

Mahrburg A.: Co to jest nauka? „Przegląd Filozoficzny” 1897/1898, R. 1, z. 1.

Mahrburg A.: Emanuel Kant. W: Pisma filozoficzne Adama Mahrburga. Red. W. SpasowsKi. T. 2. Warszawa 1914.

Mahrburg A.: Filozofia, psychologia, estetyka, etyka. „Książka” 1903, R. 3. nr 8. Mahrburg A.: Pozytywizm w opałach reakcji. „Ogniwo” 1903, nr 5.

[Mahrburg A.:] Prospekt. Wydawnictwo „Przeglad Filozoficznego”. Filozofia nowokrytyczna. „Przegląd Filozoficzny” 1901, R. 4, z. 4.

Massonius M.: Agnostycyzm. „Przegląd Filozoficzny” 1904, z. 2.

Massonius M.: Mahrburg jako uczony. „Przegląd Filozoficzny” 1914, R. 17, z. 1.

Massonius M.: Przedmowa. W: Filozofia nowokrytyczna. [Wydawnictwo „Przeglądu Filozoficznego"]. Warszawa 1905.

NowaK L.: Filozoficzno-logiczne poglady Stanisława Kobyłeckiego. „Studia Philosophiae Christianae" 1967, nr 3/1.

Schnädelbach H.: Filozofia $w$ Niemczech 1831-1933. Przeł. K. Krzemieniowa. Warszawa 1992.

Skarga B.: O kilku problemach pozytywizmu polskiego. W: Polska myśl filozoficzna i społeczna. Red. B. Skarga. T. 2. Warszawa 1975.

Skarga B., Hochfeldowa A.: Polska myśl filozoficzna $w$ epoce pozytywizmu. W: Filozofia i myśl społeczna w latach 1865-1895. Wybrały, oprac., przypisami opatrzyły A. Hochfeldowa, B. Skarga. Cz. 1. [700 Lat Myśli Polskiej]. Warszawa 1980.

Struve H.: Pozytywizm i zadania krytyczne filozofii. „Biblioteka Warszawska” 1891, T. 1.

Struve H.: Wstęp krytyczny do filozofii, czyli rozbiór zasadniczych pojęć o filozofii. Wyd. 2. Warszawa 1898.

Twardowski K.: [w dziale: Przegląd Czasopism]. „Przegląd Filozoficzny” 1897/1898, R. 1, Z. 1 .

WeryHo W.: Słowo wstępne. „Przegląd Filozoficzny” 1897/1898, R. 1, z. 1.

$Z$ historii filozofii pozytywistycznej $w$ Polsce. Ciagłość $i$ przemiany. Red. A. Hochfeldowa, B. Skarga. Wrocław 1972.

ZIELEŃCZYK A.: Drogi i bezdroża filozofii. Warszawa 1912.

Żywicki K.R. [L. KrZYWicki]: Jeden z pogromców. „Prawda” 1894, nr 41. 